\title{
Bimbingan Keagamaan dalam Membina Etika Pergaulan Santri Remaja
}

\author{
Sintia Astika, Yudi Guntara.
}

Prodi bimbingan penyuluhan Islam, STID Sirnarasa, Ciamis, Indonesia.

\begin{abstract}
ABSTRAK
Sebagai makhluk sosial yang selalu berinteraksi dengan sesama maka dibutuhkan aturan atau tatacara sehingga pergaulan berjalan dengan baik. Begitupun dengan remaja yang lebih menghabiskan waktunya dengan teman, maka perlu dibimbing untuk bisa menerapkan etika pergaulan. Penelitian ini bertujuan untuk mengetahui proses bimbingan keagamaan bagi santri remaja, presentase penerapan etika pergaulan, proses bimbingan keagamaan dalam membina etika pergaulan dan faktor pendung penghambat dalam melaksanakan bimbingan keagamaan. Adapun jenis penelitian ini yaitu penelitian deskriptif dengan jenis penelitian kualitatif pendekatan kuantitatif dengan teknik pengumpulan datanya yaitu observasi, wawancara, dokumentasi dan juga angket. teknik analisis datanya terdapat dua yaitu, teknik analisis data kualitatif berupa reduksi data, penyajian data dan kesimpulan, adapun teknik analisis data kuantitatif menghitung prentase angket. Hasil penelitian yang didapatkan bahwa terdapat beberapa macam bimbingan keagamaan yang dilakukan yaitu bimbingan membaca al-qur'an, bimbingan ibadah, bimbingan perilaku sosial, bimbingan ilmu alat dan muhadoroh. Mengenai penerapan etika pergaulan didapatkan hasil yang berkatagori baik. Adapun metode yang digunakan dalam membina penerapan etika pergaulan adalah metode keteladanan, metode kelompok, metode dars, metode khitabah, wawancara, teguran dan juga sindiran dan materinya dari kitab akhlakul banin dan mukhtarul hadits.
\end{abstract}

Kata Kunci : Bimbingan; Etika; Santri; 


\section{ABSTRACT}

As social beings who always interact with others, rules or procedures are needed so that the relationship goes well. Likewise with adolescents who spend more time with friends, they need to be guided to be able to apply social ethics. This study aims to determine the process of religious guidance for teenage students, the percentage of the application of social ethics, the process of religious guidance in fostering social ethics and the inhibiting factors in carrying out religious guidance. The type of this research is descriptive research with qualitative research with a quantitative approach with data collection techniques, namely observation, interviews, documentation and also questionnaires. There are two data analysis techniques, namely, qualitative data analysis techniques in the form of data reduction, data presentation and conclusions, while quantitative data analysis techniques calculate the percentage of the questionnaire. The results showed that there were several kinds of religious guidance carried out, namely guidance to read al-quran, guidance for worship, guidance on social behavior, guidance on science tools and muhadoroh. Regarding the application of social ethics, the results are categorized as good. The methods used in fostering the application of social ethics are the exemplary method, the group method, the dars method, the khitabah method, interviews, admonitions and also satire and the material from the book of morality banin and mukhtarul hadith.

Keywords: Guidance; Ethics; Students;

\section{PENDAHULUAN}

Remaja merupakan salah satu periode kehidupan yang dimulai dengan perubahan biologis pada masa pubertas dan diakhiri dengan masuknya seseorang ke dalam tahap kedewasaan. Kata "remaja" berasal dari bahasa latin yaitu adolescere yang berarti to grow atau to grow maturity (Elibrahim, 2011:1).

Kecamatan Panjalu merupakan salah satu kecamatan yang berada di Kabupaten Ciamis. Berdasarkan data yang diperoleh pada tanggal 25 April 2019 dari Yeti Kusmiati sebagai kepala sub bagian umum dan kepagawaian kecamatan Panjalu, bahwa jumlah penduduk pada bulan Maret 2019 sebanyak 50.187 jiwa yang terbagi menjadi dua bagian yaitu 
penduduk laki-laki berjumlah 25.389 jiwa dan penduduk perempuan 24.798 jiwa.

Adapun data jumlah penduduk berdasarkan kelompok usia yang memasuki masa remaja pada bulan Januari tahun 2018 yang diperoleh dari Ade Amir sebagai pelaksana tata pemerintahan kecamatan Panjalu pada tanggal 25 April 2019, adalah sebagai berikut, 10-14 tahun berjumlah 4.745 jiwa, 15-19 tahun berjumlah 4.429 jiwa dan 20-24 tahun berjumlah 4.103 jiwa. Salah satu desa yang berada di kecamatan Panjalu adalah desa Mandalare dengan jumlah penduduk berdasarkan usia 10-24 tahun pada bulan Januari 2018 sebanyak 902 jiwa.

Suatu penyelidikan yang telah dilakukan oleh The Menninger Foundation Topeka, Kansas City di Amerika terhadap 15.000 para teenager (belasan tahun), menunjukkan bahwa 50 persen dari mereka menginginkan mendapat kawan baru, 54 persen ingin supaya orang - orang lebih menyukai mereka dan 42 persen berhasarat menjadi orang dikenal (terkenal). Dari suatu hasil penelitian di atas dapatlah ditarik kesimpulan bahwa manusia tidak diciptakan untuk hidup sendiri dan terpisah satu sama lain. Hidup akan lebih menarik dengan adanya pergaulan, komunikasi, pertukaran pikiran dan pengalaman (Handaya, 2010:14).

Dewasa ini krisis moral dikalangan remaja sangat memprihatinkan, banyak berita yang diketahui melalui televisi, koran maupun media sosial tentang kenakalan remaja atau pergaulan yang salah, diantaranya yaitu penggunaan narkoba, seks bebas, tawuran dan juga anak dibawah umur sudah menjadi perokok aktif. Data yang diambil pada tanggal 11 November 2019 dari situs resmi badan pusat statistika (BPS) yang bersumber dari dinas sosial provinsi Jawa Barat bahwa pada tahun 2016 jumlah anak nakal di Jawa Barat yaitu 2.592 dan untuk korban narkotika berjumlah 5.935. Untuk wilayah kabupaten Ciamis jumlah anak nakal yaitu 34 dan korban narkotika berjumlah 33.

Mengutip dari situs resmi badan narkotika nasional (BNN) pada tanggal 11 November 2019 yang ditulis oleh puslitdatin, bahwa menurut Kepala Badan Narkotika Nasional (BNN) Komisiaris Jenderal Polisi Heru Winarko menyebut, penyalahgunaan narkotika di kalangan remaja makin 
meningkat. Di mana ada peningkatan sebesar 24 hingga 28 persen remaja yang menggunakan narkotika.

World Drugs Reports 2018 yang diterbitkan United Nations Office on Drugs and Crime (UNODC), menyebutkan sebanyak 275 juta penduduk di dunia atau 5,6 persen dari penduduk dunia (usia 15-64 tahun) pernah mengonsumsi narkoba. Sementara di Indonesia, BNN selaku focal point di bidang Pencegahan dan Pemberantasan Penyalahgunaan dan Peredaran Gelap Narkoba (P4GN) mengantongi angka penyalahgunaan narkoba tahun 2017 sebanyak 3.376.115 orang pada rentang usia 10-59 tahun. Sedangkan angka penyalahgunaan Narkoba di kalangan pelajar di tahun 2018 (dari 13 ibukota provinsi di Indonesia ) mencapai angka 2,29 juta orang. Salah satu kelompok masyarakat yang rawan terpapar penyalahgunaan narkoba adalah mereka yang berada pada rentang usia 15-35 tahun atau generasi milenial.

Selain itu banyak ditemukan anak usia dibawah umur sudah merokok. Penelitian Global Youth Tobacco menunjukkan tingkat prevalensi perokok remaja di Indonesia sudah sangat mengkhawatirkan. Diperkiranakan dari 70 juta anak Indonesia, 37 persen atau sama dengan 25,9 juta anak Indonesia adalah perokok dan jumlah itu menjadikan Indonesia sebagai negara dengan jumlah perokok terbanyak di Asia. Seiring dengan hal tersebut hasil riset kesehatan dasar Indonesia tahun 2013 memperlihatkaan proporsi perokok di Indonesia sebesar 24,3 persen dari jumlah penduduk, umur 10-14 mulai merokok pertama kali pada saat berumur 5-9 tahun sebesar 2,8 persen dan 10-14 tahun 97,2 persen. Sedangkan umur 15-19 mulai merokok pertama kali pada saat berumur 5-9 tahun sebesar 1,1 persen, 10-14 tahun sebesar 24 persen dan 15-19 tahun sebesar 74,9 persen (Mirnawati, dkk, 2018: 397)

Berdasarkan data di atas, banyak remaja yang salah dalam bergaul dengan teman sehingga terjerumus ke kenakalan remaja. Dalam kehidupan sehari-hari pun etika perrgaulan sudah mulai tidak diterapkan, seperti berinteraksi dengan orang tua maupun dengan guru seperti ke teman, kurangnya menghormati, begitu pun kepada teman sebaya seperti remaja yang berkata kasar kepada temannya, memanggil 
temannya dengan sebutan yang tidak pantas atau membully, bercanda kelewat batas tanpa memikirkan perasaan, menggunakan barang orang lain tanpa izin, berantem dan juga tidak bisa menyimpan rahasia.

Namun hal ini berbeda dengan remaja yang berada di desa Mandalare, berdasarkan hasil wawancara dengan Wahyu selaku kepala desa Mandalare :

"bahwa secara keseluruhan pergaulan remaja yang ada di desa Mandalare termasuk dalam kategori cukup bagus, hal ini dikarenakan remaja yang ada di desa Mandalare masih mengikuti pengajian-pengajian yang ada di madrasah sekitar lingkungannya. Namun permasalahan yang ditemukan pada remaja yaitu remaja yang dibawah umur sudah merokok. Adapun mengenai etika pergaulan masih diterapkan, seperti menghormati kepada yang lebih tua atau pun pemerintahan setempat" (Wahyu. Wawancara pribadi. 26 April 2019).

Di desa Mandalare terdapat empat pesantren salah satunya adalah pesantren Al-Amin yang terletak di dusun Taringgul. Seseorang yang menuntut ilmu di pesantren disebut dengan santri. Berdasarkan hasil wawancara dengan Enok Maesaroh selaku pembimbing agama di pesantren Al-Amin mengatakan bahwa jumlah santri di pesantren AlAmin adalah 87 orang. Santri di pesantren Al-Amin merupakan santri yang berasal dari lingkungan sekitar. Walaupun santrinya berasal dari lingkungan sekitar, namun pesantren al-amin memiliki tempat untuk santri yang mau menginap. Adapun jumlah santri yang mukim yaitu 42 orang (Maesaroh, Enok. Wawancara Pribadi. 03 Maret 2019).

Santri pesantren Al-Amin terdiri dari berbagai macam tingkatan usia, salah satunya adalah santri remaja berdasarkan hasil wawancara dengan santri remaja putri alasan mereka masih mengikuti bimbingan keagamaan adalah karena faktor lingkungan, teman dan orangtua, selain itu juga faktor dari dalam diri karena mereka ingin menambah wawasan ilmu tentang agama sehingga bisa membentengkan mereka agar tidak terbawa arus ke dalam pergaulan yang negatif (Asri, dkk. Wawancara Pribadi. 30 April 2019). 
Namun sangat disayangkan, tidak semua santri ketika bergaul dengan temannya selalu menerapkan etika pergaulan, hal ini didapat dari hasil wawancara dengan Enok Maesaroh selaku pembimbing agama di pesantren Al-Amin, bahwa terdapat beberapa remaja yang dalam pergaulan dengan teman sebayanya bertingkah laku tidak sesuai etika seperti berkata kasar, bercanda kelewat batas sehingga menimbulkan pertengkaran dan kurangnya menghargai teman, hal ini dikarenakan merasa sudah akrab sehingga dalam bergaul tidak memerlukan aturan, selain kepada teman, kepada guru etika mulai hilang seperti bersikap dan bertutur kata kepada guru seperti hal nya kepada teman (Maesaroh, Enok. Wawancara Pribadi. 03 Maret 2019).

Bimbingan agama diperlukan untuk membantu remaja dalam mencegah agar tidak berperilaku yang melanggar norma yang berlaku dan membantu remaja yang mengalami penyimpangan agar kembali menjadi baik dan tidak mengulanginya lagi. Dalam konsep behavior, perilaku manusia merupakan hasil belajar, sehingga dapat diubah dengan memanipulasi dan mengkreasi kondisi-kondisi belajar (Surya, 2003:22).

Berdasarkan hasil wawancara dengan pendiri pesantren al-amin yaitu Aep Nursobah, bimbingan agama pada remaja perlu dilakukan secara terus - menerus dan memerlukan perhatian khusus, dikarenakan masa remaja merupakan masa yang mudah terpengaruh (Nursobah, Aep. Wawancara Pribadi. 03 Maret 2019)

Berdasarkan uraian latar belakang di atas, peneliti tertarik untuk meneliti tentang pelaksanaan bimbingan keagamaan yang ada di pesantren AlAmin khususnya bimbingan agama pada remaja sehingga remaja menerapkan etika pergaulan kepada siapa pun, dimana pun dan kapan pun. Ada pun judul penelitian ini yaitu bimbingan keagamaan dalam membina etika pergaulan santri remaja pesantren al-amin.

Berdasarkan latar belakang masalah maka rumusan masalah pada penelitian ini sebagai berikut : a). Bagaimana proses bimbingan keagamaan pada santri remaja di pesantren Al-Amin?; b). Bagaimana penerapan etika pergaulan santri remaja di pesantren Al-Amin?; c). 
Bagaimana proses bimbingan keagamaan dalam membina etika pergaulan santri remaja di pesantren Al-Amin?; d). Apa saja faktor pendorong dan penghambat dalam proses bimbingan keagamaan di pesantren Al-Amin?. Penelitian ini menggunakan metode deskriptif, pendekatan kuantitatif.

\section{LANDASAN TEORITIS}

Bimbingan adalah stuatu proses membantu individu melalui usahannya sendiri untuk menemukan dan mengembangkan kemampuannya agar memperoleh kebahagiaan pribadi dan kemanfaatan sosial. Moh surya, menyebutkan definis bimbingan sebagai berikut: bimbingan adalah suatu proses pemberian bantuan yang terus menerus dan sistematis dari pembimbing kepada yang dibimbing agar tercapai kemandirian dalam pemahaman diri, penerimaan diri, pengerahan diri dan perwujudan diri dalam mencapai tingkat perkembangan yang optimal dan penyesuaian diri dengan lingkungan (Saepulrohim, $2016: 3$ ).

Kata Agama dalam bahasa Arab dan dalam Al-Qur'an disebut Din yang diulang sebanyak 92 kali. Menurut asal usul kata (etimologi) mengandung pengertian menguasai, ketaatan dan balasan. Sedangkan menurut istilah atau terminologi, din diartikan sebagai sekumpulan keyakinan, hukum dan norma yang mengantarkan manusia kepada kebahagiaan hidup di dunia dan akherat (Wahyudin dkk, 2009: 12).

Dalam buku Bimbingan dan Konseling dalam Islam, penyunting Aunur Rahim Faqih, pengertian bimbingan keagamaan Islam adalah proses pemberian bantuan terhadap individu agar dalam kehidupan keagamaannya senantiasa selaras dengan ketentuan dan petunujuk Allah, sehingga dapat mencapai kebahagiaan hidup di dunia dan di akhirat (Faqih, 2001: 61).

Menurut Enjang dan Abdul Mujib (2009: 63) dalam buku dasar-dasar bimbingan dan penyuluhan Islam, bimbingan Agama yaitu kegiatan yang dilakukan oleh seseorang dalam rangka memberikan bantuan kepada orang lain, yang mengalami kesulitan-kesulitan mental spiritual dan aktualisasi diri dalam lingkungan hidupnya, sehingga orang tersebut 
mampu mengatasi permasalahannya, didasarkan pada kesadaran atau penyerahan diri terhadap kekuasaan Allah swt, sehingga pada pribadinya timbul sesuatu cahaya harapan kebahagiaan hidup saat sekarang dan masa depannya.

Sedangkan secara spesifik yang menjadi tujuan bimbingan Islam menurut Bastaman bahwa bimbingan Islami itu selaras dengan tujuan yang akan dicapai oleh psikologi Islam. Selanjutnya Bastaman menyebutkan bahwa tujuan psikologi Islami adalah meningkatkan kesehatan mental dan kualitas keberagamaan, sudah tentu juga merupakan tujuan bimbingan Islam. Tujuan psikologi Islami ini sekaligus merupakan misi utamanya, yaitu selain mengembangkan kesehatan mental diri pribadi dan masyarakat, juga rasa keberagamaan yag terpateri dalam eksistensi manusia dan tertanam dalam relung kalbu yang terdalam (Enjang dan Abdul, 2009: 72).

Pada prinsipnya etika disebut juga sebagai ilmu normatif, sehingga etika berisi tentang ketentuan-ketentuan (norma-norma) dan nilai-nilai yang dapat digunakan dalam kehidupan sehari-hari. Berdasarkan hal tersebut Rappar membedakan etika menjadi tiga: etika deskriptif, etika normatif dan meta etika (Muchtar, 2015: 47).

Etika deskriptif menjelaskan kesadaran dan pengalaman moral secara deskriptif. Hal ini dilakukan berdasarkan kenyataan bahwa terdapat ragam fenomena moral yang dapat digambarkan dan diuraikan secara ilmiah. Etika deskriptif juga berupaya menemukan dan menjelaskan kesadaran, keyakinan dan pengalaman moral dalam suatu kultur tertentu (Muchtar, 2015: 47).

Etika normatif dipandang sebagai suatu ilmu yang mengadakan ukuran atau norma yang dapat dipakai untuk menanggapi atau menilai perbuatan. Bentuk etika ini menjelaskan tentang nilai-nilai yang seharusnya dilakukan secara memungkinkan manusia untuk mengukur tentang apa yang terjadi. Meta etika sendiri dapat disebut sebagai the philosophy ethies, yakni etika sebagai filsafat yang berusaha menyelidiki kebenaran (Muchtar, 2015: 47). 
Pergaulan berasal dari kata gaul/bergaul, dalam kamus besar bahasa Indonesia berarti bercampur dala kehidupan, berteman dengan akrab (Bambang Marhijanto, 1999: 126). Menurut Kahar Masyur (1994: 137) dalam buku yang berjudul membina moral dan akhlak mengartikan bergaul ialah hidup bersama-sama. Etika pergaulan adalah nilai - nilai dan peraturan yang digunakan oleh masyarakat untuk menentukan baik buruknya hubungan yang ada dalam masyarakat. Etika pergaulan merupakan tolak ukur identitas masyarakat terhadap sistem nilai yang dipakai (Rahmawati Erwin, 2017).

Dalam kehidupan sehari-hari, sebagai makhluk sosial maka selalu berinterkasi dengan siapa pun baik dengan orang yang lebih tua, sebaya maupun dengan yang lebih muda, dengan berbagai golongan tanpa membedakan-bedakannnya dari latar belakang kehidupannya. Rasulullah saw bersabda :

"Dari Ibn Umar ia berkata, Rasulallah saw bersabda, "orang mukmin yang bergaul dengan semua kalangan dan sabar atas gangguan mereka lebih besar pahalanya daripada orang mukmin yang tidak bergaul dengan semua orang dan tidak sabar atas keburukan mereka." (HR. Ibnu Majah)

"Dari Anas bin Malik Ra, Rasulalloh saw bersabda, "tidak termasuk, golongan kami orang-orang yang tidak mengasihi kepada yang lebih muda dan tidak menghormati orang yang lebih tua." (HR Tarmidzi)

Al-Ghazali dalam kitabnya yang berjudul Bidayatul Hidayah yang diterjemahkan oleh Abu Ali Banjari An Nadwi (1995: 161) mengemukakan bahwasannya seluruh manusia selain daripada guru, murid dan ibu bapa adalah terbagi kepada tiga ceraian; ceraian pertama yaitu orang yang tidak dikenali, ceraian kedua yaitu sahabat karib dan ceraian ketiga orang yang kita kenal (kenal saja bukan sahabat karib).

Begitupun dengan Sayyid Muhammad dalam kitab At-Tahliyah wa Targhib fi at-Tarbiyah wat Tahdzib yang diterjemahkan oleh Zaid Husein Al-Hamid menjelaskan macam-macam tingkatan manusia dalam pergaulan sebagai berikut: yang pertama adalah mereka yang lebih tinggi kedudukannya, lebih banyak ilmunya, lebih banyak kelebihannya dan 
lebih banyak adabnya darimu seperti kedua orangtuamu, guru-gurumu dan para pemimpin negerimu. Kedua, orang-orang yang setingkat denganmu seperti saudara-saudaramu yang laki-laki dan perempuan dan teman-temanmu. Ketiga, orang-orang yang lebih rendah pengetahuannya dan lebih sedikit tingkatannya darimu (Al-Hamid, 2017: 8).

Pada penelitian ini peneliti memfokuskan pergaulan kepada orang yang statusnya lebih tinggi baik dari segi pangkat, ilmu, keutamaan maupun akhlaknya yaitu kepada orangtua dan pergaulan kepada orang yang statusnya sama yaitu kepada teman, hal ini dikarenakan pada masa remaja lebih menghabiskan waktunya bersama dengan teman.

Istilah santri sebenarnya memiliki dua konotasi atau pengertian. Pertama, adalah santri yang berpengertian orang muslim shaleh yang memeluk agama Islam dengan sungguh-sungguh dan dengan teliti menjalankan perintah-perintah agama Islam sebagaimana yang diketahuinya, sambil membersihkan aqidah (keyakinan) nya dari syirik (mensekutukan Tuhan) yang terdapat di daerahnya. Dalam pengertian ini, santri dibedakan secara kontras dengan mereka yang disebut kelompok "abangan", yakni mereka yang lebih dipengaruhi oleh nilai-nilai budaya Jawa pra-Islam, khususnya yang berasal dari mistisisme Hindu dan Budha. Kedua, santri adalah siswa yang belajar di pesantren, atau mereka yang tengah menuntut ilmu di pesantren. Keduanya tampak beda, tetapi jelas juga mempunyai kesamaan, yakni sama-sama taat dalam menjalankan syari'at Islam (Hariadi, 2015: 24).

Secara etimologis, terdapat berbagai pendapat yang diajukan para ahli berkenaan dengan pengertian santri. Abu hamid memahami bahwa, kata santri adalah gabungan dari dua suku kata, "sant" yang berarti manusia baik dan "tra" yang artinya suka menolong. Dalam kerangka ini, kata santri dapat dipahami sebagai kumpulan individu-individu yang terdidik (khususnya dalam ilmu-ilmu keagamaan) yang berorentasi pada aksiaksi sosial kemasyarakatan.

Sedangkan Johns, sebagaimana dikutip Dhofier, mengatakan bahwa kata santri itu sendiri berasal dari bahasa Tamil yang berarti guru mengaji. 
Sementara menurut C.C. Berg, kata santri berasal dari kata India (Sanskerta) shastri yang berarti orang yang tahu kitab-kitab suci (Hindu), atau seorang ulama dalam pengertian Islam Indonesia. Kata shastri merupakan turunan dari kata shastra yang berarti kitab suci atau karya keagamaan atau ilmiah.

\section{HASIL DAN PEMBAHASAN}

Hasil Pesantren Al-Amin terletak di dusun taringgul desa mandalare kecamatan panjalu. Data yang diperoleh pada tanggal 05 Agustus 2019 dari Iyan sebagai kasi kepemerintahan desa Mandalare, bahwa Dusun taringgul memiliki 1 rukun warga (RW) dengan jumlah 2 rukun tetanggan (RT). Ada pun jumlah warganya yaitu 449 orang dengan rincian laki-laki berjumlah 227 dan perempuan berjumlah 222. Berdasarkan hasil wawancara dengan lurah dusun taringgul yaitu Cuncun Suryana bahwa masyarakat dusun taringgul 100 persen menganut agama Islam. Adapun mata pencaharian masyarakat taringgul yaitu dominan sebagai petani selain itu ada juga yang bekerja ke luar kota sebagai pekerja las, pekerja matrial dan ada juga yang bekerja sebagai buruh pabrik (Suryana. Wawancara Pribadi. 19 Agustus 2019).

Mengenai pergaulan remaja dusun taringgul, Cuncun mengatakan bahwa secara keseluruhan pergaulannya bisa dikatakan baik dan masih diterapkannya etika dalam bergaul, namun terkadang ada saja remaja yang berantem dengan temannya, berkata kasar, merokok namun tidak sampai ke pergaulan bebas. Menurut beliau baiknya pergaulan remaja dan masih diterapkannya etika pergaulan di dusun taringgul dikarenakan salah satu faktornya yaitu remaja masih mengikuti pengajian di pesantren. Dari banyaknya remaja yang ada di dusun taringgul sebagian besar mengikuti pengajian, hanya ada beberapa saja yang tidak mengaji dikarenakan sudah bekerja atau pun sekolah ke luar. Adanya pesantren al-amin berdampak baik bagi masyarakat dusun taringgul.

\section{Proses Bimbingan Keagamaan Bagi Santri Remaja}


Subjudul Bimbingan keagamaan di pesantren Al-Amin dilakukan setiap hari kecuali hari jum'at. Waktu pelaksanaanya yaitu tiga kali dalam sehari, pagi hari pukul 05:00 - 06:00, sore hari pukul 15:30 - 17:00 dan malam hari pukul 18:15 - 20:30. Hasil wawancara dengan Oos abdul kosim selaku pemimpin pesantren, tujuan diadakannya proses bimbingan keagamaan di pesantren al-amin yaitu membentuk santri yang berakhlakul karimah dan menjadikan santri yang mandiri, sehingga memiliki generasi penerus untuk mensyiarkan agama. Seperti dalam sebuah hadits yang mengatakan pemuda masa sekarang adalah pemimpin dimasa yang akan datang (Kosim. Wawancara Pribadi. 01 Agustus 2019).

Dalam buku dasar-dasar bimbingan dan penyuluhan Islam yang telah dijelaskan bahwa bimbingan keagamaan memiliki empat unsur yaitu mursyid, ushlub al-irsyad, maudhu irsyad dan mursyad bih. Pada pembahasan ini peneliti akan membahas bimbingan keagamaan untuk santri remaja yang berada pada tingkat tiga dan tingkat empat.

Pertama Mursyid (pembimbing) Terdapat tiga pembimbing agama untuk tingkat tiga dan tingkat empat yaitu Miftah Abdul Fatah, Oos Abdul Kosim dan juga Cece Mulyana. Kedua Mursyad bih pada penelitian ini difokuskan pada santri remaja dengan jumlah 27 santri dengan rentan usia antara 12 tahun - 17 tahun. Adapun rincian data santri berdasarkan usia nya sebagai berikut :

Tabel 1 : Data santri berdasarkan usia

\begin{tabular}{|l|l|l|}
\hline No & Usia & Jumlah \\
\hline 1 & 12 tahun & 5 \\
\hline 2 & 13 tahun & 5 \\
\hline 3 & 14 tahun & 6 \\
\hline 4 & 15 tahun & 7 \\
\hline 5 & 16 tahun & 1 \\
\hline 6 & 17 tahun & 3 \\
\hline
\end{tabular}




\begin{tabular}{|l|l|}
\hline Jumlah & 27 \\
\hline
\end{tabular}

Dalam pelaksanaan bimbingan keagamaan di dalamnya terdapat ushlub al-irsyad dan maudhu irsyad. Adapun bentuk bimbingan keagamannya adalah sebagai berikut :

Bimbingan membaca al-qur'an dilakukan secara berkelompok dengan cara ustad atau ustdzah terlebih dahulu membacakan ayat al-qur'an, lalu santri mengikutinya atau disebut dengan metode dars (pengajaran), jika terdapat kesalahan ustad atau ustadzah langsung membenarkannya. Untuk tajwid ustad atau usatdzah memberikan penjelasan dari nadom yang dipelajarinya, lalu memberikan contoh di papan tulis. Setelah itu santri disuruh untuk mencari contoh lain dari bagian tajwid yang dipelajarinya. Selain membimbing baca al-qur'an, pesantren al-amin memiliki program hafalan al-qur'an. Hafalan al-qur'an diperuntukkan untuk tingkat empat. Setoran hafalan al-qur'an dilakukan malam selasa kepada ustad cece. Berdasarkan hasil wawancara dengan santriwati tingkat empat, mereka mengatakan sudah hafal 1 juz.

Dalam bimbingan ibadah yang dibimbing yaitu sholat, wudhu, tayamum, dan ibadah haji. Materi yang membahas tentang ibadah diambil dari kitab safinah untuk tingkat tiga dan kitab riyadul ba'diah untuk tingkat empat. Metode yang digunakan tiada lain yaitu melogat kitab, setelah selesai ustad memberikan penjelasan tentang materi yang dibahas dan tanya jawab setelah penjelasan selesai. Menurut Oos abdul kosim bimbingan ibadah pun menggunakan metode praktek langsung (metode tamtsil) seperti mengajari cara sholat, wudhu, tayamum bahkan pernah praktek ibadah haji. Praktek ibadah haji ini diperuntukkan untuk tingkat remaja namun santri tingkat bawah pun berpartisipasi mengikutinya.

Sebagai makhluk sosial yang membuthkan bantuan orang lain, maka setiap harinya berinteraksi dengan yang lainnya. Dalam berinteraksi atau bergaul dengan sesama ada aturan atau tata caranya, maka santri dibimbing untuk bergaul dengan semestinya sehingga pergaulan berjalan dengan baik. Dalam bimbingan perilaku sosial akan dibahas pada bagian berikutnya. 
Ilmu alat yaitu membahas tentang ilmu nahwu dan sharaf. Ilmu alat merupakan sebuah ilmu untuk mengetahui kedudukan dan asal usul kata, adapun materi untuk memperlajari ilmu alat yaitu kitab jurumiyah dan imriti. Metode yang digunakan yaitu penjelasan dari kitab, lalu santri disuruh untuk menghafal. Untuk hafalan, santri yang baru belajar ilmu alat mensetor hafalan kepada santri yang sudah lama belajar ilmu alat (tutor sebaya). Selanjutnya yaitu narkib, dimana para santri di test untuk mengetahui sejauh mana materi tentang ilmu alat yang sudah diketahuinya.

Menurut Oos Abdul Kosim muhadoroh merupakan kegiatan untuk melatih santri berbicara di depan umum. Sebagai generasi penerus untuk mensyiarkan agama, maka perlu dibimbing dan dilatih berbicara di depan umum. Adapun rangkaian dari muhadoroh yaitu pembukaan, membacakan ayat suci al-qur'an beserta sholawat, tawasul dan pidato. Pengisi kegiatan muhadoroh yaitu santri yang dijadwal berdasarkan kobong hanya untuk tingkat tiga dan tingkat empat yang menjadi pengisi kegiatan dan dilakukan setiap malam senin minggu ke dua. Adapun pembimbingnya yaitu Miftah Abdul Fatah.

\section{Penerapan Etika Pergaulan Santri Remaja}

Selain wawancara dengan kepala desa dan juga kepala dusun mengenai penerapan etika pergaulan, peneliti juga menggunakan angket. Sebelum menghitung prosentasi hasil angket, peneliti melakukan uji validitas dan uji reabilitas terlebih dahulu.

Angket yang dibuat terdiri dari 30 pernyataan dan dibagikan kepada 27 responden, selanjutnya peneliti melakukan uji validitas untuk mengetahui tiap pernyataan valid atau invalid dengan menggunakan SPPS versi 25. Pernyataan valid jika $r_{\text {hitung }}>$ rtabel, sedangkan pernyataan invalid jika rhitung $<$ rtabel. Untuk rtabel peneliti menggunakan taraf signifikan $5 \%(\alpha=0,05)$. Adapun $\mathrm{r}_{\text {tabel }}$ yang digunakannya yaitu $\mathrm{n}=25 . \mathrm{n}=25$ didapat dari rumus $\mathrm{df}=\mathrm{n}-2$ (Syahza, 2017), maka $(27-2=25)$, sehingga diperoleh rtabel 0,396 .

Tabel 2: Hasil Uji Validitas 


\begin{tabular}{|c|c|c|c|}
\hline Item & rhitung & rtabel & Ketarangan \\
\hline 1 & 0,525 & 0,396 & Valid \\
\hline 2 & 0,147 & 0,396 & Invalid \\
\hline 3 & 0,499 & 0,396 & Valid \\
\hline 4 & 0,577 & 0,396 & Valid \\
\hline 5 & 0,247 & 0,396 & Invalid \\
\hline 6 & 0,477 & 0,396 & Valid \\
\hline 7 & 0,445 & 0,396 & Valid \\
\hline 8 & 0,529 & 0,396 & Valid \\
\hline 9 & $-0,212$ & 0,396 & Invalid \\
\hline 10 & 0,421 & 0,396 & Valid \\
\hline 11 & 0,644 & 0,396 & Valid \\
\hline 12 & 0,589 & 0,396 & Valid \\
\hline 13 & 0,557 & 0,396 & Valid \\
\hline 14 & 0,350 & 0,396 & Invalid \\
\hline 15 & 0,632 & 0,396 & Valid \\
\hline 16 & 0,229 & 0,396 & Invalid \\
\hline 17 & 0,431 & 0,396 & Valid \\
\hline 18 & 0,478 & 0,396 & Valid \\
\hline 19 & 0,487 & 0,396 & Valid \\
\hline 20 & 0,728 & 0,396 & Valid \\
\hline 21 & 0,500 & 0,396 & Valid \\
\hline 22 & 0,636 & 0,396 & Valid \\
\hline 23 & 0,400 & 0,396 & Valid \\
\hline 24 & 0,534 & 0,396 & Valid \\
\hline 25 & 0,719 & 0,396 & Valid \\
\hline
\end{tabular}




\begin{tabular}{|l|l|l|l|}
\hline 26 & 0,042 & 0,396 & Invalid \\
\hline 27 & 0,352 & 0,396 & Invalid \\
\hline 28 & 0,676 & 0,396 & Valid \\
\hline 29 & 0,468 & 0,396 & Valid \\
\hline 30 & 0,498 & 0,396 & Valid \\
\hline
\end{tabular}

Berdasarkan tabel 2, diketahui bahwa terdapat 23 pernyataan valid dan 7 pernyataan invalid pada pernyataan no 2,5,9,14,16,26 dan 27

Setelah peneliti melakukan uji validitas dan terdapat 23 pernyataan valid, maka peneliti melakukan uji reabilitas menggunakan spss versi 25 . Adapun hasilnya sebagai berikut :

Tabel 3: Hasil Uji Reabilitas

\begin{tabular}{|c|c|}
\hline \multicolumn{2}{|c|}{ Reliability Statistics } \\
\hline $\begin{array}{c}\text { Cronbach's } \\
\text { Alpha }\end{array}$ & N of Items \\
\hline, 891 & 23 \\
\hline
\end{tabular}

Dalam buku panduan penelitian eksperimen beserta analisis statistik dengan SPSS, karya i putu ade dan i gusti agung (2018: 32) terdapat tabel kriteria uji reabilitas sebagai berikut :

Tabel 4 : Kriteria Uji Reabilitas

\begin{tabular}{|l|l|}
\hline Hasil perhitungan & Derajat Reliabilitas \\
\hline $\mathrm{r}_{11} \leq 0,20$ & $\begin{array}{l}\text { Derajat reabilitas sangat } \\
\text { rendah }\end{array}$ \\
\hline $0,20<\mathrm{r}_{11} \leq 0,40$ & Derajat reabilitas rendah \\
\hline $0,40<\mathrm{r}_{11} \leq 0,60$ & Derajat reabilitas sedang \\
\hline $0,60<\mathrm{r}_{11} \leq 0,80$ & Derajat reabilitas tinggi \\
\hline
\end{tabular}




\begin{tabular}{|l|l|}
\hline $0,80<\mathrm{r}_{11} \leq 1,00$ & $\begin{array}{l}\text { Derajat reabilitas sangat } \\
\text { tinggi }\end{array}$ \\
\hline
\end{tabular}

Berdasarkan hasil uji reabilitas di atas diperoleh 0,891 maka termasuk dalam derajat reabilitas sangat tinggi.

Dalam angket etika pergaulan yang peneliti bagikan terdapat dua sub variabel yaitu etika terhadap orangtua dan juga etika pergaulan terhadap teman. Etika terhadap orangtua terdapat 3 indikator dengan total 10 item pernyataan. Adapun rinciannya sebagai berikut :

Tabel 4 : Item no 1

\begin{tabular}{|l|l|l|l|}
\hline Alternatif Jawaban & Skor & Frekuensi & Nilai \\
\hline Selalu & 4 & 9 & 36 \\
\hline Sering & 3 & 3 & 9 \\
\hline Kadang-kadang & 2 & 15 & 30 \\
\hline Tidak pernah & 1 & - & - \\
\hline JUMLAH & & 27 & 75 \\
\hline
\end{tabular}

Ket: Saya mendo'akan orangtua saya

Berdasarkan hasil penyebaran angket, diperoleh jumlah keseluruhannya yaitu 75. Dari data di atas diketahui bahwa semua santri remaja al-amin mendo'akan orangtuanya, tidak ada yang tidak mendo'akan orangtua, namun jawaban yang lebih banyak diperoleh yaitu kadang-kadang. Adapun perolehan presentasenya yaitu $, \frac{75}{108} \times 100 \%=69,44 \%$ (kategori baik).

Tabel 4 : item no 2

\begin{tabular}{|l|l|l|l|}
\hline Alternatif Jawaban & Skor & Frekuensi & Nilai \\
\hline Selalu & 4 & 6 & 24 \\
\hline Sering & 3 & 7 & 21 \\
\hline Kadang-kadang & 2 & 13 & 26 \\
\hline
\end{tabular}




\begin{tabular}{|l|l|l|l|}
\hline Tidak pernah & 1 & 1 & 1 \\
\hline JUMLAH & 27 & 72 \\
\hline
\end{tabular}

Ket: Saya membantu pekerjaan rumah

Berdasarkan hasil penyebaran angket, diperoleh jumlah keseluruhannya yaitu 72. Dari data di atas diketahui bahwa masih terdapat satu santri yang tidak suka membantu orangtuanya dan jawaban yang banyak terdapat pada alternatif jawaban kadang-kadang. Adapun perolehan presentasenya yaitu, $\frac{72}{108} \times 100 \%=66,67 \%$ (kategori baik)

Berdasarkan tabel 4.8 (saya mendo'akan orangtua) dan tabel 4.9 (saya membantu pekerjaan rumah), maka dapat diketahui presentase untuk indikator berbuat baik kepada orangtua yaitu $\frac{69,44 \%+66,67}{2}=68,06 \%$ (kategori baik)

Tabel 4.1 : Item no 1

Saya memberi tau orangtua ketika saya ingin pergi

\begin{tabular}{|l|l|l|l|}
\hline Alternatif Jawaban & Skor & Frekuensi & Nilai \\
\hline Selalu & 4 & 8 & 32 \\
\hline Sering & 3 & 6 & 18 \\
\hline Kadang-kadang & 2 & 12 & 24 \\
\hline Tidak pernah & 1 & 1 & 1 \\
\hline JUMLAH & & 27 & 75 \\
\hline
\end{tabular}

Berdasarkan hasil penyebaran angket, diperoleh jumlah keseluruhannya yaitu 75. Dari data di atas diketahui bahwa masih terdapat satu santri yang ketika keluar rumah tidak pamit kepada orangtua, dan jawaban responden terbanyak berada pada alternatif jawaban kadang-kadang. 
Adapun perolehan presentasenya yaitu, $\frac{75}{108} \times 100 \%=69,44 \%$ (kategori baik).

Tabel 4.2. Item no 1

Saya mengucapkan permisi ketika lewat di depan orangtua

\begin{tabular}{|l|l|l|l|}
\hline Alternatif Jawaban & Skor & Frekuensi & Nilai \\
\hline Selalu & 4 & 6 & 24 \\
\hline Sering & 3 & 5 & 15 \\
\hline Kadang-kadang & 2 & 15 & 30 \\
\hline Tidak pernah & 1 & 1 & 1 \\
\hline JUMLAH & & 27 & 70 \\
\hline
\end{tabular}

Berdasarkan hasil penyebaran angket, diperoleh jumlah keseluruhannya yaitu 70. Dari data di atas diketahui bahwa masih terdapat satu santri yang ketika lewat di depan orangtua tidak mengucapan permisi dan jawaban responden terbanyak terdapat pada alternatif jawaban kadangkadang. Adapun perolehan presentasenya yaitu $\frac{70}{108} \times 100 \%=64,81 \%$ (kategori baik).

Tabel 4.3 : item no 1

Saya berbohong kepada orangtua

\begin{tabular}{|l|l|l|l|}
\hline Alternatif Jawaban & Skor & Frekuensi & Nilai \\
\hline Selalu & 1 & - & - \\
\hline Sering & 2 & 3 & 6 \\
\hline Kadang-kadang & 3 & 21 & 63 \\
\hline Tidak pernah & 4 & 3 & 12 \\
\hline JUMLAH & & 27 & 81 \\
\hline
\end{tabular}


Item ini merupakan item yang berkalimat negatif. Berdasarkan hasil penyebaran angket, diperoleh jumlah keseluruhannya yaitu 81. Dari data di atas diketahui bahwa santri pesantren al-amin masih suka ada yang berbohong walaupun jawaban terbanyaknya pada alternatif kadangkadang, santri pesantren al-amin tidak ada yang selalu berbohong dalam kesahariannya. Adapun perolehan presentasenya yaitu, $\frac{81}{108} \times 100 \%=75 \%$ (kategori baik).

Tabel 4.4 : item no 1

Ketika disuruh orangtua, saya menjawab nanti dulu

\begin{tabular}{|l|l|l|l|}
\hline Alternatif Jawaban & Skor & Frekuensi & Nilai \\
\hline Selalu & 1 & 1 & 1 \\
\hline Sering & 2 & 5 & 10 \\
\hline Kadang-kadang & 3 & 20 & 60 \\
\hline Tidak pernah & 4 & 1 & 4 \\
\hline JUMLAH & & 27 & 75 \\
\hline
\end{tabular}

Berdasarkan hasil penyebaran angket, diperoleh jumlah keseluruhannya yaitu 75. Dari data di atas diketahui bahwa terdapat satu santri yang selalu menunda apa yang disuruh oleh orangtunya. Adapun perolehan presentasenya yaitu, $\frac{75}{108} \times 100 \%=69,44 \%$ (baik).

Tabel 4.5 : item no 1

Saya membantah perintah orangtua

\begin{tabular}{|l|l|l|l|}
\hline Alternatif Jawaban & Skor & Frekuensi & Nilai \\
\hline Selalu & 1 & - & - \\
\hline Sering & 2 & 3 & 6 \\
\hline Kadang-kadang & 3 & 14 & 42 \\
\hline Tidak pernah & 4 & 10 & 40 \\
\hline JUMLAH & & 27 & 88 \\
\hline
\end{tabular}


Berdasarkan hasil penyebaran angket, diperoleh jumlah keseluruhannya yaitu 88. Dari data di atas diketahui bahwa terdapat beberapa santri yang sering membatah perintah orangtua, namun lebih banyak yang menjawab kadang-kadang. Adapun perolehan presentasenya, yaitu $\frac{88}{108} \times 100 \%=$ $81,48 \%$ (sangat baik).

Tabel 4.6: item no 1

Mengucapkan tolong ketika membutuhkan bantuan orangtua

\begin{tabular}{|l|l|l|l|}
\hline Alternatif Jawaban & Skor & Frekuensi & Nilai \\
\hline Selalu & 4 & 8 & 32 \\
\hline Sering & 3 & 5 & 15 \\
\hline Kadang-kadang & 2 & 11 & 22 \\
\hline Tidak pernah & 1 & 3 & 3 \\
\hline JUMLAH & & 27 & 72 \\
\hline
\end{tabular}

Berdasarkan hasil penyebaran angket, diperoleh jumlah keseluruhannya yaitu 72. Dari data di atas diketahi bahwa terdapat beberapa santri yang tidak pernah mengucapkan tolong ketika membutuhkan bantuan orangtua dan jawaban santri terbanyak pada alternatif jawaban kadangkadang. Adapun presentasenya yaitu $\frac{72}{108} \times 100 \%=66,67 \%$ (baik)

\section{Proses Bimbingan keagamaan dalam membina etika pergaulan santri remaja}

Menurut Oos Abdul Kosim, sebagai seorang pembimbing harus mengikuti perkembangan zaman, selain itu bersikap lemah lembut, tidak ada kesenjangan antara pembimbing dengan santri ketika di luar pesantren dan akrab dengan santri, hal ini membuat santri tersentuh hatinya sehingga mau mengikuti pengajian. Seorang pembimbing harus menjalankan tugasnya dengan baik untuk membimbing klien dalam mencegah perbuatan yang tercela dan membimbing untuk berada di jalan yang lurus, seperti halnya nabi Muhammad Saw. Dalam al-qur'an Qs. AliImran: 110 yang artinya "Kamu adalah umat yang terbaik yang dilahirkan 
untuk manusia, menyuruh kepada yang ma'ruf, dan mencegah dari yang munkar, dan beriman kepada Allah. Sekiranya Ahli Kitab beriman, tentulah itu lebih baik bagi mereka, di antara mereka ada yang beriman, dan kebanyakan mereka adalah orang-orang yang fasik".

Dalam membimbing santri untuk menerapkan etika pergaulan menurut Oos Abdul Kosim terdapat beberapa metode yang diterapkan oleh pesantren al-amin :

Pertama Metode Uswah Shalihah yaitu penyampaian pesan bimbingan dalam percontohan perilaku yang teramati dan diikuti oleh mursyad bih. Menurut Oos Abdul Kosim sebagai seorang pembimbing mencontohkan perilaku yang baik kepada para santrinya. Ada pepatah mengatakan guru kencing berdiri, murid kencing berlari. Murid mengikuti bagaimana gurunya.

Kedua Materi yang membahas tentang bagaimana seharusnya manusia berperilaku kepada sesamanya terdapat dalam kitab akhlakul banin atau pun akhlakul banat dan mukhtarul hadits. Adapun yang membahas tentang tata cara seorang santri dalam menuntut ilmu untuk menuju ilmu yang bermanfaat tedapat dalam kitab ta'lim muta'alim. Pembelajaran kitab akhlakul banin dilakukan secara berkelompok mulai dari tingkat dua sampai dengan tingkat empat dan dilaksanakan pada malam minggu oleh ustad miftah, sedangkan kitab mukhtarul gadits dipelajari jika ketika kitab utama para santri sudah selesai sebelum memasuki test.

Metode yang digunakan dalam mempelajari kitab akhlakul banin yaitu metode dars (pengajaran), dimana pembimbing mengartikan kitab lalu dijelaskan maksud dari pembelajaran tersebut.

Ketiga Metode khitabah yaitu cara penyampaian melalui bahasa lisan dalam bentuk nasihat atau ceramah dihadapan mad'u kelompok kecil yang berlangsung dalam suasana dialogis dan tatap muka dengan sasaran menggugah kesadaran kalbu mursyadbih (klien) atas segala tugas kehambaan dan kekhalifahaannya (Enjang dan Abdul, 2009: 80).

Menurut Oos Abdul Kosim dalam memberikan ceramah atau motivasi kadang kala dilakukan saat semua santri bergabung pada malam senin. 
Selain pemberian ceramah secara formal, dilakukan juga secara tidak formal, maksudnya yaitu ketika di luar kegiatan pengajian. Hal ini bertujuan untuk mengingatkan kepada para santri untuk berperilaku yang baik.

Keempat Menurut Oos Abdul Kosim ketika seorang pembimbing diberi tahu oleh santri ataupun warga sekitar ketika ada santri yang berperilaku melanggar aturan, maka pembimbing tidak langsung menegur ataupun menasehatinya. Langkah awal yang dilakukan pembimbing adalah menanyakan kepada santri tersebut untuk mengetahui kebenarannya atau ada pengakuan terlebih dahulu dari santri tersebut, lalu menanyakan mengapa melakukan perilaku seperti itu.

Kelima Jika santri ketahuan langsung oleh pembimbing berperilaku tidak baik, maka pembimbing langsung menegurnya di tempat dan ketika pembimbing tidak melihatnya maka sebelum menegurnya dilakukan wawancara terlebih dahulu. Pembimbing pun menasehatinya serta memberikan pengetahuan dari dampak yang dilakukannya dan mengarahkan santri untuk berperilaku baik kepada siapapun.

Keenam Menurut Oos Abdul Kosim maksud dari sindiran disini yaitu ketika pembimbing mengetahui ada santri yang berperilaku menyimpang maka pembimbing memberikan nasehat atau mengingatkan kepada santri di saat proses belajar dalam kelas agar tidak berperilaku seperti itu.

\section{Faktor Pendukung dan Penghambat dalam pelaksanaan bimbingan keagamaan di pesantren al-amin}

Berlangsungnya suatu kegiatan tidak terlepas dari faktor pendung dan juga faktor penghambat. Hasil wawancara dengan Oos Abdul Kosim selaku pemimpin dan pembimbing agama bahwa yang menjadi faktor pendukung yaitu :

[a] Dukungan dari masyarakat yang sangat mempengaruhi berlangsungnya proses bimbingan keagamaan di al-amin, seperti masyarakat yang menyuruh anak-anaknya untuk mengaji dan juga dana yang diberikan oleh masyarakat untuk membangun pesantren al-amin. 
Tempat yang strategis jauh dari jalan besar dan juga keramaian, sehingga proses bimbingan berjalan dengan baik

Adapun faktor penghambatnya yaitu : Kurangnya sarana tempat untuk pelaksanaan bimbingan keagamaan, sehingga tempat untuk santri-santri yang mengaji di al-amin sebagain besar di rumah para ustad atau ustdzahnya masing-masing. Jika terdapat dua kegiatan secara bersamaan maka yang lebih dipilih yaitu kegiatan yang satunya bukan mengaji.

\section{PENUTUP}

Berdasarkan penelitian yang telah dilakukan, maka peneliti dapat menyimpulkan hasil penelitian sebagai berikut :

Pada tingkat tiga dan empat terdapat tiga pembimbing dengan jumlah santri yaitu 27 orang. Bimbingannya berupa bimbingan membaca AlQur'an, bimbingan ibadah, bimbingan perilaku sosial, bimbingan ilmu alat dan bimbingan berbicara di depan umum (muhadoroh). Metode yang digunakannya metode dars (pengajaran), metode tamtsil (perumpamaan), metode tanya jawab, metode hafalan dan tutor sebaya.

Berdasarkan hasil rekapitulasi angket mengenai penerapan etika pergaulan santri remaja pesantren al-amin diperoleh jumlah 1688. Adapun hasil prosentasenya yaitu 68,78\% termasuk dalam kategori baik.

Materi bimbingan dalam membina etika pergaulan santri yang kitab akhlakul banin dan mukhtarul hadits. Adapun metode yang digunakan yaitu metode keteladaan, metode kelompok, metode dars, metode khitabah, wawancara, teguran dan sindiran

Faktor pendukungnya yaitu dukungan dari masyarakat dan tempat yang jauh dari keramaian dan faktor penghambatnya yaitu kurangnya sarana tempat untuk mengaji dan jika terdapat dua kegiatan secara bersamaan.

\section{DAFTAR PUSTAKA}

Abdusshomad, M. Etika Bergaul di tengah Gelombang Perubahan. (Surabaya : Khalista, 2008). 
Ade I Putu dan I Gusti Agung. Panduan Penelitian Eksperimen Besrta Analisis Statistik dengan SPSS. (Yogyakarta : Deepublish, 2018)

Al-Ghazali, Abu Hamid. Bidayatul Hidayah (Permulaan Jalan Hidayah).

Cetakan kedua 1995. An-Nadwi Abu Ali Al-Banjari. Derang: Khazanah Banjariah.

Arikunto, Suharsini. Prosedur Penelitian Suatu Pendeketan Praktik (Jakarta: Rineka Cipta, 2013).

Aunur Rahim, Faqih. Bimbingan dan Konseling Dalam Islam (Yogyakarta : UII Press Yogyakarta, 2001).

Bertens. K. Etika. (Depok : Kansius, 2013).

Dhofier, Zamakhsyari. Tradisi Pesantren. ( Jakarta : LP3ES, 2015 ).

Elibrahim, M Nur. Psikologi Remaja (Depok: CV Arya Duta, 2011).

Emi, Suhaemi. Etika Keperawatan: Aplikasi Pada Praktik (Jakarta: Buku Kedokteran EGC, 2003).

Enjang dan Abdul Mujib. Dasar - Dasar Bimbingan dan Penyuluhan Islam (Bandung: Sajjad Publishing House, 2009).

Enjang dan Aliyudin. Dasar-dasar Ilmu Dakwah (Bandung : Widya Padjadjaran, 2009).

Handaya. Etiket dan Pergaulan (Yogyakarta : Kanisius (Anggota IKAPI), 2010).

Hariadi. Evolusi Pesantren (studi kepemimpinan kiai berbasis orientasi ESQ. (Yogyakarta : Lkis Yogyakarta, 2015).

Hurlock, Elizabeth B. 1980. Psikologi Perkembangan. Edisi ke 5. Diterjemahkan oleh: Istiwidayanti dan Soedjarwo. Jakarta: Erlangga.

Komalasari dkk. Teori dan Teknik Konseling. (Jakarta : PT Indeks, 2011).

Mahfud, Junaedi. Paradigma Baru Filsafat Pendidikan Islam. (Depok : Kencana, 2017).

Mardani. Pendidikan Agama Islam Untuk Perguruan Tinggi. (Depok : Kencana, 2017).

Marhijanto, Bambang. Kamus Lengkap Bahasa Indonesia Masa Kini (Surabaya: Terbit Terang, 1999).

Masyur, Kahar. Membina Moral dan Akhlak. (Jakarta : PT Rineka Cipta, 1994). 
Mirnawati dkk. (2018). Perilaku merokok pada remaja umur 13 - 14 tahun. Higeia. 2 (3). 397.

Mohammad, Surya. Teori-teori Konseling. (Bandung : CV Pustaka Bani Quraisy, 2003).

Muchtar, Masrudi. Etika Profesi dan Hukum Kesehatan. (Yogyakarta : Pustka Baru Press, 2015). 